\title{
Anti-p53 T-Cell Receptor-Transduced Peripheral Blood Lymphocytes
}

National Cancer Institute

\section{Source}

National Cancer Institute. Anti-p53 T-Cell Receptor-Transduced Peripheral Blood

Lymphocytes. NCI Thesaurus. Code C64773.

Human autologous peripheral blood lymphocytes (PBLs) transduced with an anti-p53 T cell receptor gene with potential antineoplastic activity. PBLs are harvested from a patient and pulsed with a retroviral vector that encodes the $\mathrm{T}$-cell receptor gene specific for a mutated form of p53. The transduced PBLs are then expanded in culture. When reintroduced to the patient, these modified PBLs express the anti-p53 T cell receptor which binds to mutant p53-overexpressing tumor cells; PBL-mediated tumor growth inhibition may follow. Many tumor cell types overexpress mutant p53 proteins, which are associated with the loss of apoptosis regulation and abnormal cell proliferation. 